\title{
English Local Authorities and the Fight against Climate Change
}

\author{
Hugh Atkinson ${ }^{1}$ \\ ${ }^{1}$ Department of Social Sciences, London South Bank University, London, England \\ Correspondence: Hugh Atkinson, Department of Social Sciences, London South Bank University, London SE1 \\ 0AA, England. Tel: 44-20-7815-5767. E-mail: atkinsh@lsbu.ac.uk
}

\author{
Received: February 19, 2013 Accepted: March 20, 2013 Online Published: July 3, 2013 \\ doi:10.5539/jms.v3n3p46 URL: http://dx.doi.org/10.5539/jms.v3n3p46
}

\begin{abstract}
The outcome of the 1992 Rio Summit (in particular Agenda 21 and the Convention on Climate Change), and subsequent international agreements right through to Rio +20 have set the context within which political leaders have sought to address the issues of climate change and sustainability. Local Agenda 21(LA21) set out a broad range of both responsibilities and opportunities for local government to tackle climate change.

This paper looks at the effects of the LA 21 strategies of a number of English local authorities. In particular, it focuses on whether such strategies have had a substantial impact on tackling climate change and promoting sustainability or if they are examples of what might be termed policy symbolism.

There will be a focus on the extent to which local communities have been active in shaping the policy agenda. Such a process of involvement is essential for sustainable, healthy and inclusive local communities as well as creating a dynamic local polity.

The paper will argue that in attempting to tackle climate change and promote sustainability, English local authorities are faced with both opportunities and constraints. How they grasp the opportunities and overcome the constraints is dependent on both their willingness to engage in a meaningful way with their own local communities, as well as effectively managing their own political resources.
\end{abstract}

Keywords: climate change, local authorities, sustainability, greenhouse gases, carbon reduction

\section{Introduction}

The fight against climate change as part of a broader strategy to create a more sustainable world is one of the biggest, if not the biggest, challenges facing politicians and decision makers. The Stern Report starkly laid out the economic, social and environmental challenges if we do not make the right choices over the next few years (Stern, 2006). To be fair, politicians and decision makers at the global, national and local level recognise the problem. Indeed there has been no lack of conferences, summits, and pronouncements from the Rio Summit of 1992 to the 1997 Kyoto Protocol and right through to the recent UN gathering in Doha. There has been a great deal of fine rhetoric, promises and warm words.

However, the reality has often failed to match the rhetoric of our political leaders. Data and evidence from the UN Intergovernmental Panel on Climate Change (IPCC) shows that greenhouse gas emissions continue to rise and along with that we have the very real possibility of global temperature increases going above 2 degrees Celsius, at which point the vast bulk of climate scientists agree things start to become very unpredictable for the future of the planet. The 2012 UN Climate Change Conference in Doha was a major disappointment to most observers with in effect key decisions put off to another day. The reasons for this are not too difficult to spot. Tackling climate change by its very nature requires long term commitments and strategies. Yet politicians often tend to think in the short term governed by the considerations of the electoral cycle. There can be no getting away from the fact that to effectively tackle climate change requires real sacrifices by voters, especially in the developed world. This requires a series of 'brave decisions' which politicians all too often seem psychologically unable or unwilling to make. In short, there is a problem of political will.

Yet before we get into a council of despair, it is important to stress that there is much good work going on in the area, not just at the global and national level, but also at the local level. It is action at the local level that is the particular focus of this paper, more specifically the role of English local authorities. Zimmerman writes of the key role that local government has to play in 'achieving global sustainability' (2012:511). Indeed the global 
gathering at the Rio Summit in 1992 recognised the crucial role that local government could and should play in combating climate change and helping shape a more sustainable world. The key role that local authorities have to play in shaping a more sustainable world was reiterated at the 2012 United Nations Conference on Sustainable Development (UNCSD, 2012:para 17). One of the key agreements that came out of the 1992 Rio summit, Local Agenda 21, includes an obligation for local authorities to draw up Local Agenda 21 plans. Central to this is engagement with local communities to raise awareness of sustainability issue such as energy efficiency, transport policy and climate change. In an English context it has been noted elsewhere how local authorities enthusiastically embraced Local Agenda 21, not least because it afforded them an opportunity to wrench back a degree of power and autonomy amidst an 18 year onslaught by a Conservative central government which seemed determined to squeeze the very life breath out of elected local government (Atkinson and Wilks-Heeg, 2000). Building on the Local Agenda 21 initiatives, many English local authorities have developed policies and strategies to combat climate change and it is to this that I now turn.

\section{The National Policy and Legal Context in the United Kingdom}

Aside from the scope for action laid out in Local Agenda 21, the ability of English local authorities (also referred to as local councils) to act in respect of climate change also has to be analysed within the specific UK policy and legal context. In formal terms, English local government has operated until very recently within the constitutional doctrine of 'ultra vires' which is translated as 'outside one's powers'. Under this doctrine, local authorities can only operate in those policy and service areas which have been sanctioned by Act of Parliament. This would suggest a fairly restricted role for English local authorities. And yet, in the 30 period following the Second World War, they played an important role in the development of the welfare state in England and the broader United Kingdom. But with the emergence of neo liberalism as the dominant policy paradigm since the late 1970s, both the welfare state in the United Kingdom and the role and influence of local authorities have come under attack. Yet, as has been argued elsewhere, English local authorities (and indeed local authorities in other parts of the United Kingdom) were able to defend their position and the services they provided in a number of creative ways (Atkinson and Wilks-Heeg, 2000).

More recently, English local authorities have been granted some additional powers. For example, the 2007 Sustainable Communities Act enshrined in statute the 'well being power' which according to central government guidelines 'enables local authorities to do anything they consider likely to promote or improve the economic, social or environmental well being of their area (CLG, 2008:5). Whilst the efficacy of the well being power has not escaped criticism, it is a power that English local authorities can call on when developing strategies and policies to fight climate change. In addition, since the coming to office of the Conservative/Liberal Democrat government in the United Kingdom in May 2010, local authorities in England have been given a power of general competence which has the potential to give English local authorities more scope for action than under the doctrine of 'ultra vires'. However, it is too early to say what impact this power will have on the ability of local authorities to tackle challenges such as climate change.

At a policy level, the 2008 Climate Change Act, passed under the then Labour government, introduced a statutory target of reducing carbon dioxide emissions by at least 80 per cent below 1990 levels by 2050 with an interim target of 34 per cent by 2020. And as Pearce and Cooper argue, the United Kingdom national government 'sees local authorities--- as uniquely placed to assist in cutting emissions and stabilising climate change---- both directly and through increasing awareness and influencing behaviour change across their communities' (Pearce and Cooper, 2011:200). The Climate Change Act also introduces the Carbon Reduction Commitment (CRC). Local authorities have to take part in the CRC, including measuring and monitoring their carbon emissions. In addition, the Act contains a new power which requires local authorities and other public bodies to report on how they have assessed the risk of climate change to their work and what actions they are taking to address these risks.

Furthermore, in December 2007 the Department for Communities and Local Government (CLG) published Planning Policy Statement: Planning and Climate Change (CLG, 2007). Its purported aim was to put tackling climate change and pursuing the broader sustainability agenda at the heart of planning with the establishment of strategic objectives at the regional and national level. However, the coming to power of the Conservative/Liberal Democrat coalition government in May 2010 has seen a shift in policy direction with the passing of the Decentralisation and Localism Act in December 2011. For the coalition government the purported aim is to remove top down targets. At first glance the localism agenda seems attractive, giving local authorities and the local communities they serve the space and opportunity to shape policy actions based on local circumstances. Indeed, it goes without saying that effective local action is key if we are to tackle climate change and build a more sustainable society. In this regard the Committee on Climate Change, a statutory body set up under the 
2008 Climate Change Act, has called on government to give strong consideration to the introduction of 'a statutory power to develop and implement low carbon plans' (Committee on Climate Change, 2012:9) Yet there is a real danger of policy fragmentation and inertia within the Coalition government's localism agenda. We need localist solutions, yes, but we would also need a strategic approach informed by such localist solutions. The government should not throw out the baby with the bath water. Indeed, the Committee on Climate Change has argued that without national indicators, there is 'a significant risk that local authorities will not develop and implement sufficiently ambitious low carbon plans' (Committee on Climate Change, 2012:9).

\section{Tackling Climate Change at the Local Level}

At the local level in England, there have been a number of local initiatives, many of them emanating from Local Agenda 21 of the Rio Summit, designed to tackle climate change and to meet the UK's commitments on the reduction of green house gas emissions.

Transition Initiatives (formerly called Transition Towns), for example, is a good example of bottom up community led action on climate change. For Chatterton and Cutler 'A Transition Initiative is a community that is unleashing its own latent collective genius to look Peak Oil and Climate Change squarely in the eye' (Chatterton and Cutler, 2007:2). It is an agenda that stresses the dangers of an economic system that is so heavily dependent on fossils fuels and calls for urgent action to move towards a more low carbon economy. Without doubt this is a major policy challenge. But Transition Initiatives is backed up by a growing national network of villages, towns and cities around Britain. There are in excess of fifty such Initiatives nationally, Totnes in Devon being the first. But there is also a global network with over sixty such initiatives in countries such as the USA, Australia and New Zealand.

At elected local government level all three main political parties, Conservative, Labour and Liberal Democrat, have areas of political control. Within each local authority the pattern and intensity of policies to combat climate and reduce carbon emissions varies. This is a product of a number of factors. These include differing ideological perspectives, levels of political leadership, policy priorities and resource levels. This notwithstanding, English local authorities have been involved in a number of important initiatives to tackle climate change. For as Buckingham and Theobold argue, local authorities 'have the capacity to facilitate and support local community actions and initiatives for environmental sustainability' and also play an important role in putting forward 'new ideas and approaches' (Buckingham and Theobold, 2003:3). Allman et al endorse this view arguing that local authorities have a 'pivotal role in developing, implementing and monitoring climate change policy' (Allman et al., 2004:275). On 9 March 2011, the then Secretary of State for Energy and Climate, Chris Huhne, signed a memorandum of understanding that recognised the pivotal role that local authorities have in tackling climate change.

A key aspect of the role of English local authorities is partnership, with local authorities working alongside community groups, third sector organisations and local business groups in developing strategies to tackle climate change. This has been formalised in the form of local strategic partnerships or LSPs.

To date, two hundred and sixteen local councils have signed up to the so called '10/10' campaign. By signing up, organisations and individuals commit themselves to reducing their green house gas emissions by ten per cent each year. Another key initiative is the Nottingham Declaration on Climate Change. Launched in 2000, the Declaration was signed by more than three hundred English local authorities. Scottish and Welsh local authorities have signed their own versions. The Declaration 'acknowledges the increasing impact that climate change will have on local communities' and commits the signatories 'to tackling the causes and effects of a changing climate'.

The Local Government Association (LGA), the representative body for UK local authorities, argues that 'Tackling climate change must be at the centre of local government's vision for their communities' (LGA, 2007:8). It is not one competing priority amongst others but 'it is the single priority which overrides all others' (LGA, 2007:8). Indeed, as the Local Government Information Unit (LGiU) notes, 'Many local authorities are already taking the lead with plans to reduce their own and the wider community's emissions'. But a step change will be needed' argues the LGiU 'to meet the challenging targets of reducing carbon emissions ... '(LGiU, 2009:4).

Indeed, the LGA has spoken of the public policy challenges of achieving greater energy efficiency and thus reducing green house gas emissions. It calculates, for example, that some ten million homes still require basic insulation. To tackle the issue of domestic energy efficiency, it calls for a more integrated policy approach designed to bring together the plethora of government funding streams to support 'systematic area based programmes to cut household fuel bills' by three hundred pounds each year, so reducing the carbon footprint by 
20 per cent (LGA, 2009a:4). For the LGA, local councils with their democratic mandate have a key role to play as a voice for local residents (LGA, 2009a:5). For the LGiU, local councillors are crucial here. In their role 'As community leaders', they 'are very tuned in to their local communities and they are best placed to communicate the issues to their constituents' (LGiU, 2010:5). The Committee on Climate Change has also noted the 'crucial role' local authorities have to play 'in reducing emissions to meet national carbon targets' (Committee on Climate Change, 2012:8). But for local strategies to be effective, argues the LGA, there needs to be active community engagement in both the design and implementation of such strategies (LGA, 2009b:.4). As Peters et al note, the role of local government is "pivotal in supporting effective community engagement to tackle climate change (2010:7597). Working in partnership with other local councils and private companies is also vital (LGA, 2009b:14). Central government also has laid great emphasis on the importance of partnership working in tackling climate change, highlighting the important contribution that third sector organisations such as environmental groups, faith groups, youth organisations and trade unions can make (H M Government, 2010:10) 'The third sector shapes the future by mobilising and inspiring others to tackle climate change and maximising the social, economic and environmental opportunities of action' (HM Government, 2010:8).

The LGA has argued that 'Developing a sustainable low carbon economy should be an integral consideration in every decision a council takes' (LGA, 2009a, p.5). This is a challenging policy objective. Yet there are numerous examples on the ground of policy innovation by local councils to tackle climate change. Reading borough council, for example, set up its Heatseekers scheme to identify those homes in the area without insulation. All private homes are being photographed using thermal imaging to show where insulation is needed and a comprehensive review of the council's housing stock is being carried out. In 2005, Harrogate borough council introduced a trial programme introducing ground source heat pumps (an efficient energy source) into a number of social housing units. The trial proved a success and the technology has now been rolled out across other social housing units (LGA, 2009b:11). Devon county council, in partnership with a number of local actors, has been promoting renewable energy in an attempt to boost the local economy. This has led to over one hundred installations in small and medium sized firms. The council has given out grants and provides advice and information on other funding streams. Cambridge city council has been involved in several initiatives. Since 1996, the energy efficiency of housing in the city has improved by forty per cent. The council uses lower emission fuels in its vehicles and requires renewable energy generation in new developments. In October 2007, it launched a climate change charter. It is a means by which local organisations can pledge their commitment to tackling climate change through their procedures and activities (Cambridge city council, 2008).

Darlington borough council (in the north east of England) has been involved in a five year project to reduce local traffic levels. Darlington was selected as one of three sustainable travel demonstrations towns, the others were Peterborough and Worcester, with grant funding for schemes to reduce traffic levels. These have included free bicycle training in local schools, the introduction of travel plans by local businesses and other local organisations (designed to encourage, for example, the use of public transport and car sharing schemes) and free travel advice for all residents in Darlington. There have been some tangible outcomes from the project. By 2008, there had been a nine per cent reduction in car journeys as people switched to public transport. Indeed, use of public transport went up by eighteen per cent. In the same year significant increases were recorded for journeys by foot and bicycle (Friends of the Earth, 2009:34).

Local councils have also been working with the Carbon Trust to develop the Local Authority Carbon Management Programme. Set up in 2001, the Carbon Trust is an independent UK wide company funded by the climate change levy and central government. One of its key roles is to support the development of UK based low carbon technologies. Over one hundred and forty local authorities have received technical and management support in an effort to reduce green house gas emissions. There have been a number of policy responses to this.

In London, the Mayor and the Greater London Authority (GLA) have been involved in a number of initiatives to tackle climate change. In July 2009 the Conservative Mayor of London, Boris Johnson, published his 'environment programme for the capital'. It talks of reshaping London as a low carbon economy and putting in place large scale programmes that can deliver significant green house gas reductions. For example, it sets out a retrofit programme of homes in the capital that could reduce emissions of green house gases by two million tonnes per year. Reference is also made to support for more sustainable energy sources (GLA, 2009:1). Per capita, Londoners have a smaller carbon footprint than the United Kingdom average, due in large part to the high usage of public transport. Despite this, both the Mayor and the GLA argue the need for concerted action. Indeed, it is forecast that unless action is taken now, London's C02 emissions will increase to an estimated 51 million tonnes by 2025 , with all the economic, environmental and social consequences that this will bring. In setting out a strategy to move towards a low carbon economy the Mayor and the GLA have made commitments of a 60 per 
cent reduction in green house gas emissions (with 1990 as a baseline) by 2025 with a target reduction of at least 80 per cent by 2050 (GLA, 2011). This is an ambitious target and will require concerted action in areas such as improved energy efficiency and big reductions in carbon emissions from public transport. Whether the policy action will match the rhetoric is something only time will tell.

Torbay council (in Devon) has committed itself to a significant reduction in green house gases from its own operations with a particular emphasis on energy usage, travel and transport and procurement policy. It is also its stated aim to actively encourage all sectors in the community 'to take the opportunity to reduce their own greenhouse gas emissions and to make public their commitment to action' (Torbay, 2008). The council has adopted a strategic plan to reduce the annual carbon emissions created by its own operations by 20 per cent by the year 2012. Colchester borough council seeks to reduce green house gas emissions from its buildings by twenty five by 2012. The council argues that 'By reducing our own emissions we can provide an example to others, enabling us to act as leaders in the wider community' (Colchester borough council, 2008:7). Cambridge city council has committed itself to a 20 per cent cut in greenhouse gases by 2020 and a reduction of eighty nine per cent by 2050 (Cambridge city council, 2008).

There are clearly a variety of initiatives at the local level which seek to tackle climate change and promote a more sustainable way of living. Many local councils have made specific commitments to reduced their green house gas emissions. But questions remain as to the substantive impact of such 'low carbon urbanism' (Bulkeley et al, 2012:5481). The LGA, whilst recognising that there are some 'outstanding examples of local council leadership' in tackling climate change, has called for a 'more urgent and consistent authority wide approach ... by each and every local authority' (LGA, 2007:9). The environmental lobby group, Friends of the Earth, has called for 'a step change in local action by local councils'. It has argued that much greater ambition is 'needed in local emissions cuts if councils are to play their part in meeting the national targets set out in the Climate Change Act' (Friends of the Earth, 2009:4). Friends of the Earth readily accepts that 'local government is in a strong position to lead and co-ordinate' action against climate change and that 'many councils are taking climate change very seriously...' but argues that 'most councils are being left behind' (Friends of the Earth, 2010:1). What is required is 'A nationwide system' that will support 'councils and ensure emissions come down in every local authority' (Friends of the Earth, 2010:1). Accordingly, Friends of the Earth has called for all local councils to have a local carbon budget and to set out a firm commitment (with a detailed action plan) to cut emissions in their area by 40 per cent by 2020 . But they also argue that support from central government is vital in the form of more resources to develop green technologies. The prospects for such central government support in the current climate of large scale cuts in public expenditure are uncertain to say the least. But without 'institutional capacity' at local government level there will be 'a growing gap between the rhetoric' and 'the realities of governing climate change on the ground' (Bulkeley et al, 2012:547).

However, as part of its localism agenda, the coalition government in 2010-11 ran a pilot programme with 9 local authority areas to co-design a series of Local Carbon Frameworks (LCF) in an attempt to identify what works at what spatial level and to develop strategies for action on carbon reduction by all local authorities. The LCF pilots provide a good example of how councils, if they are given the opportunities, can rise to the challenge and tackle the issue of climate change.

The evaluation of the LCF pilots was published by the Department of Energy and Climate Change (DECC) in 2011. Bristol city council, for example, led 9 projects aiming to reduce carbon emissions and tackle climate change. One was the creation of a carbon costing toolkit to provide information on the costs and savings of reducing green house gas emissions (DECC, 2011:44). Leeds city council carried out a small scale study to see how investment in low carbon energy technologies in the commercial office rented sector could be encouraged and developed. It found that lack of information on the benefits of more sustainable technologies was a bigger barrier to action in this sector than funding. Strategies are being put in place to address this (DECC, 2011: 73). Dorset county council set up a web based resource to support community groups seeking to utilise more sustainable forms of energy. A key lesson from Dorset was that the success of such projects is contingent on a strong and existing relationship with community groups (DECC, 2011:20).

\section{Some Case Studies}

To gain a clearer understanding of the role of English local authorities in the fight against climate change, in addition to the broad survey in the previous part of this paper, I have also undertaken a more detailed and in depth analysis of 3 specific local authorities. The three case studies involve local councils with varied party political control and a diversity of demographic factors. As such, they provide some useful insights into what local authorities are doing on the ground. My 3 case studies are: 
The London borough of Croydon

2) Manchester city council

3) Cheshire east council

It is helpful to provide a brief biography of each local authority area. The London borough of Croydon is on the southern most fringes of Greater London. Currently run by the Conservative Party, the local authority demonstrates some of the inner city characteristics of social deprivation but it also has a number of very affluent suburbs.

Manchester city council in the north west of England is a mixture of both urban and suburban areas with significant social deprivation sitting alongside areas of relative affluence. The Labour Party dominates the local political scene. Cheshire East council is also in the north west of England but that is where the similarity ends. Whilst it does contain some areas of urban deprivation, Cheshire East has in its boundaries some of the wealthiest areas in England. It is the home to many highly paid Premiership footballers (or soccer players). David Beckham of LA Galaxy fame used to have a house there. It is dominated politically by the Conservative Party.

These three case studies give us a good sense of the direction of travel with regard to policies to reduce carbon emissions. A more detailed analysis of the success of these policies will require further research as substantive targets to be measured only come into play from 2015 onwards.

\subsection{The London Borough of Croydon}

Firstly, I will consider the case of the London borough of Croydon. Working through the local strategic partnership, the Croydon Environment and Climate Change Partnership, the London borough of Croydon published its Climate Change Mitigation Action Plan in 2010. Under the action plan, it has set a strategic green house gas emissions reduction target of 34 per cent by 2025 for the borough as a whole focussing on both its in house activities and those in the wider community. The baseline for measurement is the year 2005. In addition, it has also set a number of interim targets. For example, by 2015 it aims to reduce green house emissions by 15 per cent (London borough of Croydon, 2010:16). The action plan builds upon a number of other policy initiatives such as Croydon's 2010 borough wide transport strategy and the Mayor of London's 2010 transport strategy. In its action plan Croydon talks of its commitment to promoting more sustainable modes of transport. There is, for example, a focus on behavioural change, encouraging local people to cycle, walk, join car clubs and invest in electric vehicles (London borough of Croydon, 2010:5). In terms of public transport, there has been a significant investment in a network of electric tram routes.

In addition, an energy efficiency strategy has been put in place. In the first phase, a series of area based home energy efficiency retrofit programmes were launched in the autumn of 2010. In the second phase running from 2015 to 2025, the focus will be on 'full house retrofit' of some 40,000 homes with a 'package of measures including solar thermal technology, solid wall insulation, floor insulation and draft proofing' (London borough of Croydon, 2010:6). A strategy to promote energy efficiency in the commercial and industrial sector is also in place.

A partnership and community engagement approach seems evident in Croydon's strategy to reduce green house gases with an emphasis on working with faith and community groups and local businesses (London borough of Croydon;16). Plans have been put in place for a communications and marketing strategy to promote and encourage behavioural change.

At first sight, it would appear that a number of substantive measures have been put in place by the local authority to tackle green house gas emissions within Croydon. Time will tell how effective they have been. However, a possible weakness with Croydon's policies and plans to reduce green house gases is that they are not set within a broader sustainability strategy. Indeed when I contacted the sustainable development and energy team at Croydon I was told that the local authority's work on sustainability was focussed almost exclusively on energy. The implications of this will require further research. Nonetheless, at a political level, there is within the cabinet of elected councillors (the key decision making body within the local authority) a cabinet member with a specific policy brief for sustainability, transport and planning which does seem to point to political buy in. However, there is a separate brief for regeneration and economic development (2 areas which are inextricably linked to sustainability) held by another cabinet member. This could lead to policy fragmentation. 


\subsection{Cheshire East Council}

Cheshire East council has set out its strategy to reduce green house gas emissions in the shape of the Carbon Reduction Plan which it has developed in co-operation with the Carbon Trust and its local strategic partnership Partnerships for Action in Cheshire East. The council boldly states that 'By 2016 Cheshire East council will be a low carbon council' (Cheshire East council, 2011:5). In an attempt to achieve this, the council has set a target of a 25 per cent reduction in green house gas emissions by 2016, with 2008 as the baseline year. The reduction plan is framed by a number of strategic aims. These include;

- Delivering cost savings from carbon reduction activities in council buildings, schools, transport and street lighting

- $\quad$ Developing a portfolio of carbon reduction projects (including sustainable procurement).

- $\quad$ Reducing the demand for energy (Cheshire East council, 2011:11)

At the present time Cheshire East council does not purchase 'green energy' due to the cost implications but is instead purchasing energy from combined heat and power sources (CHP).

Unlike Croydon where the green house gas reduction strategy was community wide, in Cheshire East the targeted reductions only apply to the council's own in house activities. This seems to suggest a somewhat limited ambition. However, there are some references to the broader community. These include:

- Inspiring staff and members (elected councillors) to contribute to the delivery of actions and initiatives (to reduce green house gases) across the wider community

- Leading the community on climate change by demonstrating leadership in the reduction of green house gas emissions

- $\quad$ Enhancing awareness of school pupils through the curriculum (Cheshire East council, 2011:11)

But the unlike the London borough of Croydon, Cheshire East has a documented sustainable community strategy. It sets out a number of policy priorities the purpose of which is 'to improve the quality of life of all the people of Cheshire East and to contribute to the achievement of sustainable development through action to improve economic, social and environmental well being across the area' (Cheshire East council, 2010:5).

At the political level within the council, there is a cabinet member with a portfolio for environmental services but with no reference to broader sustainability issues. However, within the bureaucracy there is a climate change officer, an energy manager and an official responsible for sustainable procurement. The council has a number of what they term 'Eco Reps' who promote sustainability within the organisation.

\subsection{Manchester City Council}

Manchester city council has set out a strategy which seeks to reduce green house gas emissions across the city of Manchester as a whole, not just in the Council's own internal operations. It has set a target reduction of 48 per cent by 2020 and 80 per cent by 2050 (in line with national targets) with 1990 as the base line. Yet the council recognises that such targets cannot be met if the scenario is merely one of business as usual. To deal with the challenges, it has set out a set of climate change principles. These include:

- $\quad$ working in partnership with a wide range of organisations

- $\quad$ encouraging and supporting personal behaviour change towards lower impact modes of living

- $\quad$ growing Manchester's expertise and capacity in sustainable technologies

- $\quad$ building climate change awareness into mainstream learning (Manchester, 2009:13)

Key to a successful strategy is the requirement to ' bring local grass roots community based collective action together with the influence, capacity and resources of organisations in government and business' (Manchester, 2009:4).

Although I could not locate a separate sustainability strategy, Manchester city council's plan of action on green house gas reduction is set within the context of broader concerns about sustainability. There is an emphasis on the need for communities to work together to improve the environment and to live healthier and more sustainable lives (Manchester, 2012). The action plan talks of the major opportunities for job creation in the emerging low carbon technology sector which provides a real opportunity to tackle worklessness in the city. Plans to adapt to climate change such as greening the city will, the council argue, provide habitats for plants and animals and support the delivery of the Manchester Biodiversity Strategy (Manchester, 2009:7). 
At an officer level, responsibility for tackling climate change lies within the Department of Environmental Services. There is a dedicated 'Green City project officer' and a 'Head of Climate Change, Building and Energy'. In respect of political responsibility, there appears to be no Cabinet member with a specific brief for climate change and broader issues of sustainability. There is, however, a cabinet member with responsibility for the environment covering transport policy, green issues (including waste) and planning. The council leader and the 2 deputy leaders do not have any stated responsibility for climate change or sustainability. This might be of significance and will require further investigation.

\section{Conclusion}

In this paper I have tried to give an insight into the way in which English local authorities have approached the battle against climate change. There are good examples of such local authorities showing a real policy commitment to reduce greenhouse gases by means of strategies to improve energy efficiency and to reduce traffic. But the picture still remains very mixed. Indeed, the environmental pressure groups, Friends of the Earth has argued that 'most councils are being left behind' (Friends of the Earth, 2010: 1) and in fact the response of English local authorities to the challenge of climate change is patchy. What is needed is for central government to provide a national context which energises, supports and gives discretion and greater policy autonomy to local authorities. For too long local government in England has been subject to the vagaries of central government control and diktat. When New Labour came to office 1997, it seemed to presage the very real possibility of a rejuvenated local government system with more devolved powers, both policy making and financial. Yet when New Labour was voted out of office in May 2010, there had been little substantive change. The arrival in office in May 2010 of a Conservative/Liberal Democrat coalition government with its talk of a new localism and greater decentralisation has, for the present at least, not seen the rhetoric matched by significant policy action. Indeed, local authorities in England are having to operate in a very challenging financial environment with budget cuts of some 30 per cent over the next 4 years. But English local authorities (or at least a significant number of them) have in their DNA the ability and creativity to respond to difficult challenges. This has been demonstrated on many occasions in the past (Atkinson and Wilks-Heeg, 2000). With the right political will, English local authorities can play their role in meeting the challenges of climate change.

\section{References}

Allman, L., Fleming, P., \& Wallace, A, (2004). The Progress of English and Welsh Local Authorities in Addressing Climate Change. Local Environment, 9(3), 271-293. http://dx.doi.org/10.1080/1354983042000219379

Atkinson, H., \& Wilks-Heeg, S. (2000). Local Government from Thatcher to Blair: The Politics of Creative Autonomy. Cambridge: Polity Press.

Buckingham, S., \& Theobold, K. (Eds.) (2003). Building alliances for environmental sustainability. Local Environmental Sustainability. Cambridge: Woodhead Publishers.

Bulkeley, H., Broto, V., \& Edwards, G. (2012). Bringing climate change to the city: towards low carbon urbanism? Local Environment: The International Journal of Justice and Sustainability, 17(5), 5456-551.

Cambridge City Council. (2008). Cambridge Climate Change Strategy and Action Plan. Cambridge, Cambridge City Council.

Chatterton, P., \& Cutler, A. (2007). The Rocky Road to the Transition Town Movement and What it Means for Social Justice. Leeds, Trapese.

Cheshire East Council. (2010). Ambition for All; Cheshire East's Sustainable Community Strategy. Cheshire East Council.

Cheshire East Council. (2011). Cheshire East Council Carbon Management Programm. Cheshire East Council.

CLG. (2007). Planning Policy Statement: Planning for Climate Change. London, HMSO.

CLG. (2008). Practical Use of the Wellbeing Power. London, HMSO.

Colchester Borough Council. (2008). Local Authority Carbon Management Programme. Colchester, Colchester Borough Council.

Committee on Climate Change. (2012). How local authorities can reduce emissions and manage climate risk. London, Committee on climate Change.

DECC. (2011). Evaluation of the Local Carbon Framework Pilots. London, HMSO.

Friends of the Earth, Briefing. (2010). Local Carbon Budgets. London, Friends of the Earth. 
Friends of the Earth. (2009). Cutting Carbon Locally and How to Pay for it. London, Friends of the Earth.

GLA. (2001). Delivering London's Energy Future: the Mayor's climate change mitigation and energy strategy. London, GLA.

GLA. (2009). Leading to a Greener London: An Environment Programme for the Capital. GLA, London.

H.M. Government. (2010). Shaping Our Future- The Joint Ministerial and Third Sector Task Force on Climate Change. The Environment and Sustainable Development. London, HMSO.

LGA. (2007). A Climate of Change- Final Report of the LGA Climate Change Commission. London, LGA.

LGA. (2009a). The Economy or the Environment, Do I Need to Choose? London, LGA.

LGA. (2009b). From Kyoto to Kettering, Copenhagen to Croydon- Local Government's Manifesto for Building Low Carbon Communities. London, LGA.

LGiU. (2009). Carbon Trading Councils. London, LGiU.

LGiU. (2010). Getting Ready for a Changing Climate. London, LGiU.

London Borough of Croydon. (2010). Croydon Climate Change Mitigation Plan. Corydon, London Borough of Croydon.

Manchester City Council. (2009). Manchester Climate Change- Call to Action. Manchester, Manchester City Council.

Pearce, G., \& Cooper, S. (2011). Sub-national responses to climate change in England: evidence from local area agreements. Local Government Studies, 37(2), 199-217. http://dx.doi.org/10.1080/03003930.2011.554825

Peters, M., Fudge, S., \& Sinclair, P. (2010). Mobilising community action towards a low carbon future: Opportunities and challenges for local government in the UK. Energy Policy, 38(12), 7596-7603. http://dx.doi.org/10.1016/j.enpol.2010.01.044

Planning and Climate Change Coalition. (2010). Guidance and model policies for local authorities. Town and Country Planning Association London, 2010.

Stern, N. (2006). Stern Review on Economics of Climate Change. London, HMSO.

Torbay Council. (2008). Carbon Management Plan: Working Together to Reduce our Carbon Emissions. Torbay, Torbay Council.

UNCSD. (2012). The Future We Want. New York, United Nations.

Zimmermann, K. O. (2012). From Rio to Rio+20: the changing role of local governments in the context of current global governance. Local Environment: The International Journal of Justice and Sustainability, 17(5), 511-516.

\section{Copyrights}

Copyright for this article is retained by the author(s), with first publication rights granted to the journal.

This is an open-access article distributed under the terms and conditions of the Creative Commons Attribution license (http://creativecommons.org/licenses/by/3.0/). 